Fall 1999

\title{
Corruption and Legitimation Crises in Latin America
}

Ángel Oquendo

University of Connecticut School of Law

Follow this and additional works at: https://opencommons.uconn.edu/law_papers

8 Part of the Comparative and Foreign Law Commons, Law and Politics Commons, and the Law and Society Commons

\section{Recommended Citation}

Oquendo, Ángel, "Corruption and Legitimation Crises in Latin America" (1999). Faculty Articles and Papers. 49.

https://opencommons.uconn.edu/law_papers/49 


\section{HEINONLINE}

Citation: 14 Conn. J. Int'I L. 4751999

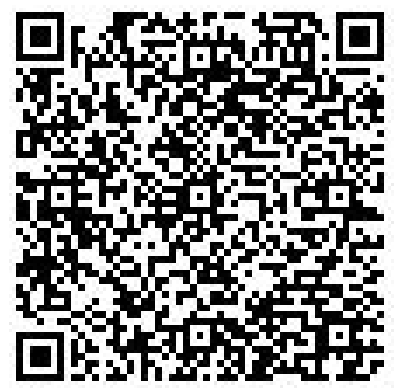

Content downloaded/printed from

HeinOnline (http://heinonline.org)

Mon Aug 15 17:14:59 2016

-- Your use of this HeinOnline PDF indicates your acceptance of HeinOnline's Terms and Conditions of the license agreement available at http://heinonline.org/HOL/License

-- The search text of this PDF is generated from uncorrected OCR text.

-- To obtain permission to use this article beyond the scope of your HeinOnline license, please use:

https://www.copyright.com/ccc/basicSearch.do? \&operation $=$ go\&search Type $=0$ \&lastSearch $=$ simple\&all=on\&titleOrStd $N o=0897-1218$ 


\title{
CORRUPTION AND LEGITIMATION CRISES IN LATIN AMERICA
}

\author{
Ángel Ricardo Oquendo*
}

\section{INTRODUCTION}

It is all too evident that a pervasive corruption problem may undermine a government's legitimacy. Citizens lose faith in political and legal institutions and may become cynical or rebel. Ultimately, the very survival of the system may be at stake. This paper deals with these issues but at a rather specific conceptual level. In particular, I intend to explore the notion of a legitimation crisis and its implications for the issue of political corruption in Latin America. This exercise will make it possible to understand more precisely how it is that corrupt practices debilitate the state's claim to justification.

It was Joel Paul who suggested that I address this topic at the Connecticut Journal of International Law's conference entitled "Political Corruption in Market Democracies." I must confess that my initial reaction was one of puzzlement. After all, German philosopher Jürgen Habermas originally applied the notion of a legitimation crisis to developed or even over-developed countries. Habermas, in fact, called the book that introduces the terminology Legitimation Problems in Late Capitalism. ${ }^{2}$ It was Thomas McCarthy's translation that rendered the title simply Legitimation Crisis. ${ }^{3}$ How could such a notion apply to present-

* Professor of Law, University of Connecticut School of Law. Ph.D., 1995, M.A., 1995, A.B., 1983, Harvard University; J.D., 1986, Yale University. I would like to say thanks to Peter Goldstone and Ernesto Garzón Valdés for their helpful insights.

1. The event took place on November 12-14, 1998, at the University of Connecticut School of Law in Hartford, Connecticut. Please see Symposium articles/speeches published concurrently in this volume.

2. JÜRGEN HABERMAS, LEgITIMATIONSPROBLEME IM SPÄTKAPITALISMUS (1973) [hereinafter Habermas, legttimationsprobleme]. See Leslie holmes, The End of Communist Power: ANTI-CORRUPTION CAMPAIGNS AND LEGITIMATION CRISIS 28 (1993) ("As the German title suggests, Habermas' book is explicitly and primarily concerned with advanced industrial society organized along predominantly capitalist lines.").

3. JÜrgen HABERMAS, Legitimation CRISIS (Thomas McCarthy, trans., 1975) [hereinafter HABERMAS, LEGTTIMATION]. 
day Latin American nations, which are the quintessence of underdeveloped - or, more euphemistically, "developing," and, up to several months ago, even considered "emerging" - economies? These countries have in the last decade experienced, contrary to the proverbial late capitalism, a drastic reduction rather than an expansion of state intervention. Instead of instituting the welfare state, these polities have been in the business of dismantling anything bearing it even the slightest resemblance.

It occurred to me at first that in deploying this concept with heavy Marxist overtones in an underdeveloped context which had yet to meet the conditions of application, ${ }^{4}$ Joel was just displaying his Leninist inclinations - of course, Leninism with a human face. Upon deeper reflection, I realized that the notion of a legitimation crisis does indeed illuminate the problem of corruption in Latin America. If properly reinterpreted, the concept enables one to understand political corruption as an endemic threat to the normative identity of society. The appropriate response, accordingly, cannot be simply technical - such as the enactment of tougher laws or the implementation of more effective enforcement mechanisms. Nor can it be merely motivational, in the sense not of Habermas but rather of U.S. psychologist David McClelland. ${ }^{5}$ That is, one cannot just seek to change the attitude or the prevailing professional culture in civil service. Instead, the challenge is to transform the way in which Latin American communities understand themselves, particularly the normative premises of their social integration. In other words, a metamorphosis of the underlying democratic principles is necessary.

\section{CRISIS}

Let me get to work here. I should first note that the expression "legitimation crisis" appears in conjunction with the issue of corruption in a book edited by Leslie Holmes entitled The End of Communist Power: Anti-Corruption Campaigns and Legitimation Crisis. ${ }^{6}$ The subject matter there is, of course, the battle against corruption in the former Soviet block. Yet, the reasons Holmes invokes for applying the concept of legitimation crisis beyond the iron curtain are not relevant to Latin America. She avers, in particular, that by loosening their grip on the economy, Eastern European Communist governments were effectively contradicting their

4. See HABERMAS, LegitimationSPROBleme, supra note 2, at 10-11.

5. Compare David C. McClelland, Human Motivation (1988); David C. McClelland, achievement Motive (1980); David C. McClelland, Human Motivation: a Book of Readings (1973); David C. MCClelland, Motivating EConomic ACHIEVEMENT (1971) with HABERMAS, LegitimationSPROBleme, supra note 2, at 106-28 ("Motivation Crisis").

6. HOLMES, supra note 2. 
own ideology, and thus losing their credibility.' This argument may bear on the situation in Cuba, but not much on the rest of the Iberian American region. $^{8} \quad$ Moreover, Holmes does not see corruption as a cause of a legitimation crisis but rather as a concomitant development. ${ }^{9}$

I will therefore start from scratch. I will be loading on many certainly too many - tentative and undeveloped thoughts, which will ineluctably render the presentation somewhat convoluted. By way of compensation, I will conclude with some reflections on the direction the discussion should take from here on. My hope is that this contribution will be the beginning rather than the end of a debate.

Habermas begins his discussion with an examination of the medical interpretation of the notion of a crisis..$^{10}$ From this standpoint, an organism faces a crisis when attacked by a disease - a virus or bacteria - in a way that endangers the target's very existence. Habermas insists that when a crisis involves human beings, a subjective dimension inevitably arises." What he means is that in determining whether and to what extent survival is at stake, one must take the perspective of the person herself - her notion of well-being, of life, of who she is. At this turn, Habermas recognizes his debt to the dramaturgical usage of the term. In this sense, "a crisis means the turning point of a fateful process, which objectively does not either simply break in from the outside or remain external to the identity of the affected person."

It is clear where Habermas is coming from. A true son of the Frankfurt school, he is moving towards an internal application of the concept to societies. He is continuing the process of formulating a critical theory, modeled on Karl Marx and Sigmund Freud, which works together with its subject in identifying the problem and in deciding what the solution should be. In this interpretation, Marx does not offer his critique from the point of view of someone who has stepped outside, decided how society should function, identified current deficiencies, and proposed specific improvements. Instead, he formulates his assessment of and proposed solutions for the problems of capitalism internally, i.e., from the

7. Id. at 32 .

8. The term "Iberian America" denominates the former New World colonies of Spain and Portugal-the two nations on the Iberian Peninsula. Mexico and Brazil are examples. This expression is more accurate than "Latin America", which should presumably also include once-French possessions, such as Haiti or Québec, but ordinarily refers only to Iberian America. See Ángel R. Oquendo, "Reimagining the Latino/a Race," 12 HARV. BLACKLETTER J. 93, 96-99 (1995). In this essay I use the two concepts interchangeably, following the common, albeit imprecise, usage.

9. Id. at 34 .

10. HABERMAS, LegitimationsPROBLEME, supra note 2 , at 9.

11. Id.

12. Id. at 10 . 
proletariat's perspective. Similarly, Freud supposedly does not simply seek to gather evidence on his patients' disorders and then figure out what the cure should be. On the contrary, he purports to work with his subjects so that they can themselves identify the problem, find a remedy, and determine whether the treatment has been effective. ${ }^{13}$

Habermas generally elaborates a critical theory along similar lines. In his earlier work he postulates an ideal speech situation through which individuals themselves agree upon how to transform their collective existence, guided exclusively by the force of the better argument. ${ }^{14}$ More recently, he advocates discursive and deliberative democracy as a process through which people are able reasonably and autonomously to deal with modern life's fundamental challenges. ${ }^{15}$

It should therefore come as no surprise that Habermas finds the internal or subjective notion of a crisis appealing. He readily incorporates the concept into his societal analysis. For him, a society hits a crisis when it confronts an onslaught on its identity and a clear prospect of extinction. Its only hope of survival is to undergo a radical transformation. In order to overcome the crisis, however, it will have to do more than change its essence. It will also have to be able to recognize itself in its new form, which may be a truly agonizing feat. ${ }^{16}$

I could draw on the cliché of crises being both a crossroad and an opportunity and assert that a crisis both endangers a community and allows it to grow. Yet, I will resist the temptation to go kitsch. I will only say that a crisis forces its subject not only to draw on its self-preservation instincts, but also to engage in a most demanding self-examination exercise. The subject must reflect profoundly on who it is, and on the limits of its identity.

\section{LEGITIMATION CRISIS}

Enough about crisis. What about legitimation? I think it is useful at this point to keep in mind the notions of modernity, rationalization, and disenchantment, which Habermas borrows from Max Weber. I'll bring them in as I go along.

Legitimation, generally, refers to the production of norms that move people to support social institutions. Society can, accordingly, bring its

13. See generally, JÜRGEN HABERMAS, ERKENNTNIS UND INTERESSE (1973) thereinafter

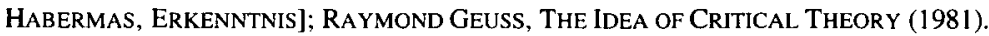

14. See, e.g., Habermas, ERKenntnis, supra note 13; Jürgen Habermas, Theorie des KOMMUNIKATIVEN HANDELNS (1981) [hereinafter HABERMAS, KOMMUNIKATIVEN].

15. See JÜrgen Habermas, Faktizität und Geltung: Beiträge zur Diskurstheorie des RECHTS UND DES DEMOKRATISCHEN RECHTSSTAATS (1992) [hereinafter HABERMAS, FAKTIZITÄT].

16. See generally, HABERMAS, LEGITIMATIONSPROBLEME, supra note 2, at 9-19. 
members to comply with institutional strictures through force or through legitimation. It usually relies, of course, on both. Yet, the more it can persuasively claim to be legitimate, the less it will have to use repression, and (presumably) the more stable it will be.

Following Weber, Habermas explains that in pre-modern societies, legitimacy feeds off broadly accepted philosophical or theological worldviews. If anybody demanded a justification for the power wielded by social institutions, the establishment would probably appeal to metaphysical or religious beliefs shared by all. It would perhaps maintain that the existing order finds a "raison d'être" in the teachings or commandments of the community's deity or deities."

In the modern world, however, the phenomenon described by Weber as "disenchantment" takes place. ${ }^{18}$ As society becomes increasingly complex and pluralistic, all-encompassing and monolithic worldviews will not do. They can no longer justify in one swoop the multiplicity of components that make up the social structure, nor, in light of the diversity of convictions, gain the approval of the entire population. Modern legitimacy, therefore, rests not on mythical tales, but on independently persuasive reasons. ${ }^{19}$ This conception overlaps globally with that of "basic legitimacy" recently postulated by British philosopher Bernard Williams, which does not exhaust political virtue but which, in Williams' words, "implies a sense in which the state has to offer a justification of its power to each subject."

Habermas takes over Weber's idea that social structure breaks down into specialized institutions, which call for their own justificatory resources and which must secure the allegiance of a plurality of individuals who do not share a particular creed. Habermas adds, to this Weberian account, the contention that there is a cognitive content to the legitimating norms, which goes beyond their mere factual acceptance and which makes full sense only internally. ${ }^{21}$

I will now attempt to combine the two concepts of Legitimation and Crisis. As I already intimated, according to Habermas, dysfunctions of the kind once identified by Marx plague advanced capitalism and make intensive state economic involvement necessary. Inasmuch as state controlled economic activity does not have the level of naturalness and

17. See Habermas, Fatkizität, supra note 15 , at 181. See also MAX Weber, Wirtschaft UND GESELLSCHAFT 16-20, 122-40, 822 (1976).

18. See, e.g., WEBER, supra note 17 , at 308 .

19. See Habermas, Kommunikativen, supra note 14, at 262-98; Habermas, FakTizität, supra note 15 , at 42 .

20. Bernard Williams, Realism and Moralism in Political Theory 7 (Apr. 24, 1997) (manuscript presented at the Yale Legal Theory Workshop).

21. See HABERmas, KommuniKativen, supra note 14 (Band I), at 255-66. 
ready-acceptability of the market, a legitimation gap emerges. Habermas describes the legitimation crisis at stake as follows: "The legitimating system is not able to sustain the necessary level of mass loyalty in carrying out the steering imperatives taken over from the economic system."22

The idea is that, at the outset, the state presents and justifies itself as a guarantor of the free market. Its mission is basically to preserve a framework within which capitalist production and exchange can flourish. As business cycles become ever more common and intense, the government must intervene. It has to perform investment and redistribution functions in order to keep the economy going and to provide a safety net for those disenfranchised by the workings of capitalism. In doing so, however, it transgresses the laissez faire dogma, which until then was its main source of legitimacy. A crisis thus emerges and persists until the state is able to secure additional justifications for its unprecedented role. It overcomes its predicament only when it is able to produce some kind of welfare state or social market ideology.

Habermas underscores that this is an "identity crisis", which signifies that society's self-understanding - that is, the set of norms through which society interprets itself and attains social integration - is at risk. It has to produce new norms, which ultimately might either fail to provide the necessary legitimacy or come across as foreign and alienating. It must, more concretely, replace the tenets of libertarianism with those of social welfarism, and hope that the latter will not only adequately justify its government's expanding economic incursions, but also be compatible with its self-understanding. The endogenous form and the focus on identity are what distinguish this crisis from the original economic crisis that launched the entire process to begin with. Whereas the latter crisis involves problems in system integration, the former is about difficulties in social integration, to use the terminology that Habermas takes from David Lockwood. $^{23}$ In other words, while the economic crisis endangers society's capacity to operate as a coherent system, the legitimation crisis threatens its ability to act and understand itself as a fully unified community.

22. HABERMAS, LEGITIMATIONSPROBLEME, supra note 2 , at 68

23. David Lockwood, Social Integration and System Integration, EXPLORATIONS IN SOCIAL Change 244 (Zollschand \& Hirsch eds., 1964), quoted in Habermas, LegITIMATIONSPROBleme, supra note 2 , at 17 . The notions of social and system integration have continued to pervade even Habermas' later work. See HABERMAS, FAKTIZTTÄT, supra note 15, at 46-47, 50, 51-52, 54-55, 56, $57,58-59,61,65,66,70-71,78,110-11,172-73,217,363,450,524,643-44$. 


\section{CORRUPTION AND LEGITIMATION CRISIS}

At this point, I may sweep in the issue of corruption. This matter seems, at one level, to be about system integration, i.e., about the state's capacity to perform its compensation or coordination role in the economy. A corrupt state is not in the position, for example, to undertake its redistributive function or to provide the needed judicial certainty in an effective manner. That is, on the one hand, state officials constantly embezzle the funds that the legislature appropriates for welfare programs or, on the other hand, judicial decisions often end up being a function not of pre-established rules, but rather of the extent to which the parties have bribed the decision makers.

Chronic corruption may, nevertheless, additionally impinge upon social integration. The citizenry typically loses faith in the individuals in front of as well as the principles behind the leading political and administrative institutions. The social cohesion and solidarity built on those norms begin to wane. For instance, notions such as democracy, the rule of law, or civic rights may gradually lose their appeal.

Under these circumstances, a crisis of sorts unfolds. The polity's subsistence as a normatively consolidated unit is in peril. Above all, it is the identity of the collectivity that is at stake. The convictions through which the various individuals see themselves as belonging together are on the verge of a total collapse. The government will be hard pressed to come up with a new set of norms to justify its employees' abuses and unify its constituents. It will gradually end up with no other option than repression to stay in power and to keep the society from disintegrating. This course of action, needless to say, is awfully unstable and unlikely to be effective in the long run.

Nevertheless, this situation does not constitute a classical legitimation crisis. Political and legal institutions are, to be sure, engaging in action for which they lack normative backup. Yet, they are not, as in the paradigmatic scenario, undertaking a necessary task that overextends existing legitimacy resources. They are instead involving themselves in activities that are superfluous, aberrant, and intrinsically illegitimate.

A legitimation crisis of sorts emerges only when the state adopts anticorruption measures that call for additional normative cover. A serious campaign to combat corruption may lead, for instance, to a restriction of traditional privacy rights or to the elimination of some of the longestablished privileges of power. Political and legal institutions will, accordingly, have to modify their ground principles so as to allow the anticorruption effort. The extent of the crisis will depend on how difficult it is for the people to embrace these new norms. 
An anti-corruption effort along these lines will normally, at most, entail a mini-crisis. Usually the normative readjustment required will not seriously menace the community's identity. Under certain circumstances, however, dealing with widespread corruption may call for an approach that dramatically shakes up the polity. It may demand, for instance, not simply fine-tuning, but actually radically re-interpreting the political norms in place. The effectiveness of the anti-corruption crusade in such a context will be a function of the state's capacity to revamp the principles that structure the nation's politics, as well as the people's ability to identify with the novel set of norms.

I can make the point in plain language thus: Confronted with a severe corruption problem, a society may have to do more than pass an ethics code or come up with reliable enforcement mechanisms. It may even have to go beyond altering some isolated political norms. It may additionally have to engage in a profound reflection on the principles of government. It may need to reconfigure the premises of its political unity and selfunderstanding. This process will be arduous and, at times, traumatic.

What I have in mind is a situation in which at first the approach to politics is mostly instrumental. Political actors generally regard the principles of politics as instruments through which to achieve certain ends. They treat their activity as a game. They form tactical alliances and, if successful, divide up the spoils of battle with their allies. They thus fancy politics as a continuation of war by other means, to flip over Clausewitz's famous aphorism. ${ }^{24}$ They are certainly aware that they ought to follow the rules, but ultimately their focus is on their own objectives. They therefore decide whether to follow the established commandments in a particular case on the basis of whether doing so is consistent with their broader goals.

In this picture, private citizens have a rather passive role. Their political involvement is intermittent, limited to when elections or referenda come up. At most other times, they hibernate politically. A key part of the politicians' strategy, of course, consists in trying to obtain the support of these constituents during the electoral season. The end is to get the vote with any means available. In their pursuit of this aim, political agents again face certain restrictions with which they must comply or else risk facing penalties for noncompliance.

If there is a problem of rampant corruption under these circumstances, an anti-corruption project may not be terribly useful. Political players will tend to view the ethics prohibitions as simply an additional set of precepts

24. See generally, CARL von Clausewitz, Vom KRIEGE (1952) ("War is nothing but a continuation of politics by other means."). 
around which they must act. They may find ways of violating the spirit while honoring the letter of the law or ways of simply avoiding detection. Accordingly, the society may be hopelessly incapable of stopping the erosion in legitimacy caused by the uncontrolled abuse of power.

In such a case, it is necessary to overhaul the instrumental in favor of a more reflexive understanding of politics. In other words, the state should try to move individuals to visualize their political engagement as an end in itself. These persons will, hence, come to see politics as an ongoing process through which the community exists as such and gives itself the law by which it lives. This collective autonomous effort takes a multiplicity of forms: dialogue, argument, self-definition, deliberation, negotiation, emotional outburst, bonding, inner rivalry, as well as gamesmanship. The latter is part of but does not dominate the political universe. Thus, politics ceases to be merely about strategizing, and political norms map out not an obstacle course, but an intrinsically meaningful existential space, within which the community becomes its own master.

From this perspective, the political world encompasses everyone, not just politicians. The public sphere plays a crucial role in political life. Citizens are no longer simply a source of electoral support and become, through their civic organizations, an immanent element in the political process. They bring forth initiatives, ideas, and criticisms. They may, depending on the issue, work along with, against, and independently of their representatives. They must, in any case, be an integral part of the communal self-legislation struggle.

This reflexive approach to government corresponds to what Ernesto Garzón Valdés, following H.L.A. Hart, denominates "the internal point of view." "25 Garzón Valdés maintains that to confront political corruption head on, it is necessary to "make sure that decision makers adopt an internal point of view with respect to the basic rules of the relevant normative system. ${ }^{26} \mathrm{He}$ notes that taking this internal point of view implies moving to a deeper understanding of democracy.

Corrupt acts and activities are just the tip of the iceberg. They suggest the existence of a more profound problem: the tendency to substitute the ideal of democratic cooperation with forms of competition and the exercise of influence, which are radical contradictions of the democratic ideal . . . Thus, the

25. Ernesto Garzón Valdés, "Acerca del concepto de la corrupción" 10 (unpublished manuscript, on file with author).

26. Id. at 18 . 
recuperation of modernity's democratic faith - and the implementation of proposals to make possible a coexistence in conditions of equality are the best means of avoiding the disintegrating effects of corruption in democratic society. ${ }^{27}$

Garzón Valdés would probably agree with me, then, that, in order to come to grips with corruption, government officials, alongside the rest of society, must sometimes rise to a reflexive conception of politics. In this conception the underlying norms represent not externally imposed strictures, but rather internally chosen principles of self-definition and self-legislation.

This kind of political vision will go a long way towards creating an atmosphere propitious for controlling corruption. Individuals in positions of power will have an inclination to regard the parameters that regulate their endeavors, including ethical precepts, as crucial components of a shared communal existence and, as such, worthy of respect. Corrupt government officials and citizens may lose not only points, but also crucial credibility with themselves as well as with others. They will be cheating not just the system, but themselves in a very fundamental way. Ordinary citizens will have the tools and incentives to discover and expose the violations. In this environment, it will be considerably easier to have a transparent and accountable government system.

Moving towards such a conception of politics may very well bring about a grave crisis. What is at stake is the way in which the polity understands itself. On the one hand, it may not have the means to undergo such a radical transformation. On the other hand, even if it does have the capacity, it may not be able to recognize itself in its altered state. In either case, its survival will be on the line.

This situation will entail a legitimation crisis that differs from the one contemplated by Habermas in more than details. First, the governmental action that unleashes the whole predicament, i.e., the war against corruption, is not a response to external economic imperatives but rather to a legitimacy problem. Though dishonesty in government may bog down the economy, it typically gets major attention only when it hurts the state's credibility and brings about a public outcry. 
Figure 1. Legitimation Crisis: (i) Classical and (ii) Corruption Scenarios

\begin{tabular}{|l|l|l|l|}
\hline $\begin{array}{l}\text { Original } \rightarrow \\
\text { Dysfunction }\end{array}$ & State Response $\rightarrow$ & Legitimacy Gap $\rightarrow$ & Normative Adjustment \\
\hline (i) Economic Crisis & State Intervention & Beyond Laissez Faire & Welfare State Ideology \\
\hline (ii) Corruption & Anti-Corruption & $\begin{array}{l}\text { Beyond } \\
\text { Instrumentalism }\end{array}$ & Reflexive Politics \\
\hline
\end{tabular}

I can illustrate this first point with Figure 1, which depicts the structure of a legitimation crisis. The original dysfunction, which prototypically takes the form of an economic crisis, is a situation of pervasive corruption. The state response is not compensatory intervention in the economy but rather an anti-corruption campaign. My contention is that the case at hand diverges from the paradigm not only in these particulars, but also in that the original dysfunction already involves legitimacy difficulties.

The second difference is that the state response is one that challenges directly (not as a side effect) the community's normative selfinterpretation. In the first scenario, the state's actions purport to address the initial complication and, incidentally, bring about a need for normative readjustment. In the second, the solution to the original difficulty requires a re-adaptation to begin with. Thus, eradicating systematic corruption demands immediately transcending instrumentalism, and moving to a reflexive approach to politics.

Figure 2. Corruption's Legitimacy Challenge

\begin{tabular}{|l|l|l|l|}
\hline $\begin{array}{l}\text { Systematic } \\
\text { Corruption } \rightarrow\end{array}$ & $\begin{array}{l}\text { Legitimacy } \\
\text { Deficit } \rightarrow\end{array}$ & $\begin{array}{l}\text { Anti- } \\
\text { Corruption } \rightarrow\end{array}$ & $\begin{array}{l}\text { Radical } \\
\text { Re-Conceptualization } \\
\text { of Legitimacy }\end{array}$ \\
\hline
\end{tabular}

These considerations suggest a reconstructed model of the legitimacy challenge presented by the problem of corruption. As represented in Figure 2, a situation of systematic corruption leads directly to a legitimacy deficit. Even under an instrumental conception of politics, rampant corrupt practices pervert the political game and prevent people from taking it seriously. The solution is a radical anti-corruption plan, which entails a re-conceptualization of legitimacy. That is, in order to justify their actions, political actors will have to show not that they generally abide by the rules in pursuing their strategy, but rather that they normally treat politics as an end in itself. 


\section{LATIN AMERICAN CORRUPTION}

So much for corruption generally. What about Latin American corruption? Turning my attention to this region will force me, first, to illustrate the general pronouncements I have already made. The theory will thus have to descend to a more concrete plane. Second, in Latin America the conceptual framework will have the opportunity of showing its explanatory power. In particular, the notion of a legitimation crisis can explicate the current Iberian American corruption problem while distinguishing it from its previous incarnations. Finally, applying my theoretical contemplation to the specific situation will enable me to make some helpful modifications to my abstract model.

Political corruption is in fact part of a larger phenomenon, i.e., the dichotomy between valid and effective law, which both Mexican legal scholar Jorge Witker and Argentine legal philosopher Ernesto Garzón Valdés have posited as characteristic of Latin American law. ${ }^{28}$ What they mean is that the law on the books diverges from the law on the streets. Constitutions, for instance, promise all sorts of rights, which citizens rarely enjoy in practice. ${ }^{29}$ Similarly, the law commands government officials to act in a certain way, yet they will often either do the opposite when appropriately bribed, or condition their performance on an extortionate fee.

It is depressing to think that Witker identifies this bifurcation of law and reality as a defining feature of Latin American law in 1975, whereas Garzón Valdés does the same on his own in 1997. The evils of corruption, in particular, seem as present today as twenty years ago. Has there been absolutely no progress in two decades? "Plus ça change, plus c'est la même chose?" The more things change the more they remain the same?

I will argue that there is a key difference between the past and the present experience of corruption. I will maintain that what distinguishes today's corruption is precisely the fact that it is accompanied by a sense of crisis. Yet, I will first take on the contention that the phenomenon not only is exactly the same throughout, but also should not be a source of concern. In this way, I will be able to precise further the notion of a legitimacy deficit and how it bears on the issue of corruption.

28. See Jorge Witker Velásquez, Derecho, desarrollo y formación jurídica, 2 ANUARIO JURíDICO, INSTITUTO DE INVESTIGACIONES JURIDICAS 295, 299-300 (1975); Emesto Garzón Valdés, Eine kritische Analyse der Funktionen des Rechts in Lateinamerika, 23 IBEROAMERIKANISCHES ARCHIV. ZeITSCHRIFT Für SOZIALWISSENSCHAFTEN UND GESCHICHTE, (Neue Folge) 321, 323-24 (1997).

29. See Luis A. Ortiz-Álvarez \& Jacqueline Lejarza, Estudio preliminar: constituciones latinoamericanas. Nuevas tendencias, carácter normativo $e$ interpretación constitucional, CONSTITUCIONES LATINOAMERICANAS 9, 11-12 (1997). 
Inasmuch as corruption seems to be a way of life in Iberian America, some might suggest not getting too worked up about the issue. Perhaps "corrupt" practices simply perform a different role in Latin America than in the North Atlantic world. Maybe they are just part of an informal tax system, or they function similarly to paid consulting services. Is it not the case that underpaid police officers often take bribes to raise their salaries when the system is unable to do so due to inefficiency or insensitivity? Is there really a significant difference between a graft payment demanded by a well-placed government official and the fees charged by a consultant when both are performing essentially the same service? Are both not simply helping a corporation obtain the necessary authorization from high up? Can it be that the anti-corruption clamor in Latin America is just the product of excessive moralizing, or of an attempt to apply Western concepts in a remote context?

A sanctimonious attitude may, to be sure, preclude a clearheaded analysis of the causes, workings, and consequences of governmental dishonesty. The discussion should therefore not end with the crucial observation that under conditions of pervasive corruption those with access to power benefit at the expense of everybody else. There is, furthermore, no denying that corruption operates differently in Latin America than it does in developed countries. Realizing how corrupt acts in Latin America parallel perfectly legal practices farther north is indeed helpful in gaining a critical understanding of Latin American corruption as well as of North Atlantic legality.

One should nonetheless keep in mind that corruption, when epidemic instead of episodic, generally impairs the state's functionality and legitimacy. I will first address the functional impediments. A society sets up political and legal institutions with an eye to realizing certain objectives. If these institutions operate randomly because of the dishonesty of their personnel, they will not be able to attain these goals. If their overall organization is even minimally rational, this kind of distortion is detrimental to the community. As an example of dysfunctional corruption, one may think of a transportation agency that is in charge of developing a subway system and is unable to complete some of the lines because officials embezzle the funds.

Political corruption renders the government deficient not only functionally, but also from the standpoint of legitimacy. When the state is corrupt, the rule of law and democracy suffer. The polity's capacity to act with legality and autonomy diminishes. A community honors the notion of legality, when it applies its norms in a consistent and principled manner. It is autonomous, when it gives itself the law by which it lives. Corruption implies, on the one hand, an arbitrary implementation of norms 
and, on the other hand, an adoption of norms that do not faithfully reflect the people's will. The law state and the democratic state may gradually collapse.

When legal precepts establish, for instance, that government contracts will go to the best bid, the rule of law requires the consideration of all bidders equally and objectively. The winner should be she who makes the least expensive proposal while meeting the previously specified quality criteria. If the decision-makers instead choose an undeserving contractor who has advanced a payment under the table or demand an extortionate fee in order to approve the most meritorious project, they are acting capriciously and not in accordance with the principle of legality.

In the same example, the assumption is that the legal norm expresses the general will. If the state officials conduct themselves as expected, they will be serving as vehicles through which the community governs itself. The community has decided that it will do business with those who offer it the most advantageous deal and, through its public servants, it does so. When its agents let money influence the process and ignore the preestablished parameters, it ends up under the coercion of precepts someone else has foisted upon it.

Latin American governments, to be sure, are already functionally and legitimately handicapped to some degree. They are often inefficient and unethical. Insofar as they are even minimally functional and legitimate, however, political corruption represents a loss. Moreover, it is precisely the culture of corruption that, to a significant extent, renders them dysfunctional and illegitimate. It is therefore inappropriate to treat government dishonesty as simply a curious feature of Iberian American countries.

As previously noted, corruption is not really a constant in recent Latin American history. The manifestations of this phenomenon have changed over time. They were different twenty years ago than they are today. Being aware of this evolution is key to understanding corruption and to finding a solution to the problem.

I have already pointed out that what is new is the sense of crisis. Yet, why does there seem to be a crisis now when corruption has been a Latin American tradition for so long? I do not mean, of course, to insinuate that corruption and the broader disjunction between valid and effective law represented no problem twenty years ago. What I am saying is that the difficulties appear to take a different form today. They now have the feel of a legitimation crisis. The threat seems to be no longer simply to system integration, but also to social integration. Political corruption appears to incapacitate not only the government's functionally, but its legitimacy as well. 
Where does this change come from? It is tempting to search for an explication in the fact that twenty years ago corruption took place within the bounds of a paternalistic over-expanding state, whereas now there is a minimalist evanescing state in place. This contrast is relevant, as I will point out later on, but is not, in my opinion, the decisive factor. Instead, the key distinction is that today the move towards democracy is widespread throughout Latin America. With the exception of Cuba and Puerto Rico, the nations of the region appear to be in the process of erecting systems in which political decision making takes place democratically. Needless to say, how far down this path each country has gone varies immensely. Yet, at present, Latin American regimes across the board must secure legitimacy for their actions. In the past, they could in many cases simply resort to force. This option seems more and more to be unavailable.

So, government dishonesty in Latin America now leads to the legitimacy deficit that set the crisis process in motion. Twenty years ago, when dictatorships were predominant in the region, the consequence was mostly a shortage of functionality. The authoritarian states were often willing to put up with this deficiency. Naturally, they also lost legitimacy points. They distanced themselves from the ideal of legality. Yet, they generally did not depend on their claim to legitimacy to stay in power. They could conduct themselves arbitrarily, and coerce their citizens into compliance when necessary. Furthermore, because they never seriously pretended to serve the community's autonomy, the democratic deficit associated with political corruption was pretty much beside the point.

In this day and age, with the advent of Latin American democracy, rampant corrupt practices lead to legitimacy insufficiencies that can be lethal. When Iberian American democracies fall prey to increased arbitrariness, their precious claim to legality erodes. Their concurrent deterioration towards heteronomy implies at least a partial abdication of their democratic status. All the same, today they may not resort to force as readily and openly as they did in the past in order to make up for the justification gap.

An explanation along these lines is clearly incomplete. Although the democratic revival means that the states must rely on rational legitimation rather than on shared tradition - or even violence - to obtain their citizens' loyalty, it does not in itself point to a crisis. Actually, as anticipated by the paradigm introduced in the previous section, the crisis derives from the need for an identity-threatening radical transformation, not from minor adjustments to come to terms with systematic political corruption. Iberian American countries are in this predicament because they generally operate with an inadequate conception of government. 
In fact, the democratization process in Latin America has been highly deficient for the most part. The understanding of politics that is emerging in the region is overly instrumental. Political actors play the democracy game strategically instead of engaging in genuine democratic interaction. The oligarchies in power realize that they must win elections in order to live on. They undertake grand publicitary efforts, often devoid of real content, to capture votes. The end result is not a real development but rather a trivialization of the democratic process. On this point, the U.S. influence seems to have been pernicious.

Under these circumstances, the state can barely arrogate to itself the legitimacy it so vitally needs. It perpetuates itself not on the basis of publicly defended and defensible reasons, but instead through propagandistic manipulation and sometimes through force. Of course, I am exaggerating and caricaturizing a bit here. Nonetheless, the political ascent of Fernando Henrique Cardoso in Brazil and Carlos Menem in Argentina - let alone that of Alberto Fujimori in Peru - is attributable more to clever politicking and advertisement than to an authentically democratically advocated political program. Even the Revolutionary Institutional Party - the PRI - in Mexico has figured out that it can exchange images instead of cash for ballots and thus preserve its political hegemony without openly and deliberately confronting the grave problems affecting the nation.

In setting in motion their "neo-liberal" agendas - i.e., those based on trickle down economics - Iberian American states have sidestepped any seriously democratic debate. The dismantling of the bare-bones welfare administration that had emerged over the years and the euphoric privatization campaigns have taken place without a profound, communitywide consultation. More to the point, the old "corruptocracy" has learned quickly how to adjust and cash in on the new political programs.

Latin America faces a general legitimacy gap due first and foremost to the perversion of the democratic ideal, but also to the undermining of the rule of law and the solidarity ideal. Political corruption aggravates the normative deficiency by pushing Latin American societies even farther away from the principles not only of autonomy and legality, but also, as I will note below, of equality. Within this atmosphere, anti-corruption efforts seem to be useless. State officials find ways of dodging the proscriptions or sanctions. Often, those in charge of enforcement are already - or become - part of the corruption nightmare.

Thus interpreted, Latin American corruption does fit the legitimation crisis model sketched earlier. Systematic corruption leads to a legitimacy deficit in the form of the collapse of the rule of law, on the one hand, and genuine democracy, on the other hand. Because of the instrumental 
interpretation of politics in place, ordinary anti-corruption mechanisms are insufficient.

Notice how within this strategic conception of government, the claim to legitimacy is weak from the outset. Public servants already carry themselves somewhat arbitrarily and without enough regard for the general will. Nonetheless, pervasive corruption further undermines the state's legitimacy. The end result may be not just an altered set of effective norms, but a wholly different kind of game. Public and, even more importantly, private citizens may finally simply refuse to play altogether.

At any rate, the survival of these communities is on the line. If they do nothing, they could very well perish as integrated collectivities. What they need to do to subsist is reinvent the premises of their social unity. That is, they must move from an instrumental to a reflexive understanding of their political culture. They have to conduct themselves thoroughly according to the principles of legality and autonomy. They must, consequently, re-conceptualize their legitimacy. Yet, if they succeed in transforming themselves in this way, they might well not be able to recognize themselves. Their dilemma is that, whereas the present situation may be unsustainable, the future prospect may turn out to be alienating. Their challenge is simultaneously to re-construct and re-imagine themselves.

Reflecting on how this large-scale metamorphosis would unfold in Latin America makes it evident that the concept of legitimacy will have to expand beyond the principles of legality and autonomy to incorporate that of solidarity. Iberian American nations have failed to complete the creation not only of the law state and the democratic state but also of the social state. The political and economic reforms of the last decade and a half have not sufficed to eliminate systematic arbitrariness or heteronomy and have, in some ways, even increased inequality. Political corruption, for its part, brings about arbitrariness and heteronomy directly, while it entrenches inequality indirectly. It has this indirect effect because it typically works like a regressive tax. It usually benefits individuals with contacts in the spheres of influence, who are usually better off, at the expense of everybody else, particularly of the poor. As Latin America evolves toward a reflexive conception of politics and a new reading of legitimacy, it will come closer to the three ideals: legality, autonomy, and solidarity. Combating government dishonesty through the broader approach, i.e., through an overall shift from instrumentalism to reflexivity, is a significant part of this process of evolution. 
Figure 3. Dimensions of Legitimacy

\begin{tabular}{|l|l|l|l|}
\hline State Conception & Action Principle & Contrary Principle & Overarching Ideal \\
\hline (i) Democratic State & Autonomy & Heteronomy & Democracy \\
\hline (ii) Social State & Equality & Inequality & Solidarity \\
\hline (iii) Law State & Legality & Arbitrariness & Rule of Law \\
\hline
\end{tabular}

In my discussion of legitimacy, I have been referring to three dimensions. Each of them comes with a set of related principles, ideals and visions of the state. For the sake of clarity and completeness, Figure 3 spells out the conceptual apparatus. To be legitimate a state must, first of all, be democratic. It has to act according to the principle of autonomy, i.e., it must be the means through which the community self-legislates. It must, to turn to the other side of the coin, avoid placing its citizens in a position of heteronomy. Obviously, its overarching ideal has to be that of democracy. It needs, moreover, to function as a social state. It has to promote equality, guided by the ideal of solidarity. Finally, it must be a law state, which follows the principle of legality and avoids arbitrariness. Its global goal in this sense has to be that of the rule of law.

The question remains, of course, how it is that Latin America can reach the reflexive approach to politics and the new conception of legitimacy and thus create a better environment in which to combat corruption. The solution is to embed ideals such as democracy, the rule of law, and solidarity in the constitutional texts and practices. The devil, as usual, is in the details. I will only make a few general suggestions, keeping in mind that the trajectory will ineluctably be arduous, uncertain, and nonlinear.

The democratic process should focus on allowing the citizenry to govern itself. Candidates for office should prevail on the basis of the objective appeal of their programs - i.e., of how much the community can freely make their agenda its own - not of how well they play the game of politics. Money should, therefore, have much less influence on the outcome, which would probably require limiting campaign spending to a pre-established amount paid by the state. There should be strict restrictions on the extent to which the winners are able to reward their supporters with positions in public service.

These last two suggestions would undoubtedly also advance the principle of legality. To advance further in the same direction, state officials should receive a decent wage, so that they are better able to fulfill their duties in a principled and honest fashion. Government should, at any rate, operate more transparently at all levels. The public sphere should become stronger, through government funding of private groups and initiatives. Citizens would then have the possibility of engaging 
themselves more directly in the self-determination process, and of monitoring the work of their representatives and public servants.

Education should improve in order to empower all individuals, not only politically - but also socially. Thus, individuals would be capable of enlightened political and civic engagement as well as of economic and existential flourishing. The goal of solidarity inevitably would also call for income redistribution and a welfare safety net. Latin American society should specifically take pains not to leave the poor or minority groups behind. It should equip the traditionally disadvantaged to contribute meaningfully to social, political, and economic progress.

In addition to these reforms at the national level, international institutions should emerge that are also committed to the principles of legality, autonomy, and equality. Consequently, the current Latin American integration movements should focus not only on economic, but also on legitimacy norms. Transnational structures should have the authority and the capacity to enforce these norms effectively.

Severe sanctions and anti-corruption laws, on the national and international plane, will naturally always play an important role. They will, however, be all the more successful, the more Latin America approaches a new conception of politics and legitimacy through the kind of broad measures just outlined. My main point is that, inasmuch as Latin American corruption has brought about a legitimation crisis, the only way out is precisely a radical transformation of the premises of collective existence.

\section{CONCLUSION}

I have now closed the circle. My discussion set off from the idea of a crisis and then entered into the more specific notion of a legitimation crisis. I then explained how political corruption may entail this kind of a predicament. Finally, I construed Latin American corruption in terms of a legitimacy crisis. The Leninist reconstruction of the original concept is thus complete.

Much more work remains. The theoretical constructs need further elaboration and precision. I have, moreover, only scratched the surface of what the practical consequences might be. The central task at this point is probably the development of a program that creatively breathes life into abstract ideals such as the rule of law, democracy, and solidarity.

Most Latin American nations have, of course, already constitutionally committed to these goals. Nevertheless, they have barely started out towards effective implementation. The divergence between valid and effective law is immense at a time in which these communities' 
subsistence depends on a convergence. My contention is that there has not been sufficient understanding of these guiding notions or of the kind of metamorphosis that their full realization demands.

The Latin American corruption crisis explodes with the legitimacy deficit produced by rampant government dishonesty. Iberian American societies are, more importantly, incapable of stopping their own decline into arbitrariness, heteronomy, and inequality without undergoing a vertiginous transmutation process. Ordinary measures and the usual anticorruption tactics are hopeless. Furthermore, naked state violence as a means of shoring up the allegiance or at least the obedience of the citizenry has ceased to be a real alternative. The only survival option is, therefore, for these communities to gather the courage to reinvent themselves. They must regenerate their democratic potential, move towards a more substantive and less instrumental model of democracy, and come up with appropriate legislation and enforcement mechanisms. More broadly, they must build a political and legal structure capable of sustaining not only a genuinely democratic state, but also a law state and a social state.

This ambition is, as already admitted, more easily promulgated than realized. Yet, I remain optimistic that democracy - even when highly defective - cannot defy its own logic. It is inescapably reflexive and therefore cannot bracket out meta-questions about its premises or about the framework in which it unfolds. Nor can it shut off reflection on its connections to the principles of legality and equality. Latin American peoples, consequently, must simply persevere, with honesty and courage, in their effort to open up politically. If they do so, they will hopefully be able to visualize a new democratic horizon and come to see themselves reflected in it. 